\title{
Histological and biochemical studies of mice kidney after exposure to mobile phone radiation
}

\author{
Ali Louei Monfared ${ }^{*}$, Aaref Nooraii ${ }^{2}$, Morteza Shamsi $^{3}$
}

1. Department of Basic Sciences, Faculty of Para-Veterinary Medicine, University of Ilam, Ilam, Iran

2. Department of Veterinary Histology, University of Urmia, Urmia, Iran

3. Department of Parasitology, Faculty of Medicine, Ilam University of Medical Sciences, Ilam, Iran

*Corresponding author:Tel: +98 8412224308 Fax: +98 8412224308

Address: Department of Basic Science, Faculty of Para-Veterinary Medicine, University of Ilam, Ilam, Iran E-mail: alm722@gmail.com

Received: 2015/11/21 revised; 2015/12/3 accepted: 2016/01/6

\section{Abstract}

Introduction: There are general concerns about the hazardous impacts of the cell phones radiation on the human health. In this study, the structural and biochemical changes of the mice kidney were assessed after cell phone exposure in.

Materials and methods: A total of $40 \mathrm{Balb} / \mathrm{C}$ mice were randomly divided into the control and experimental groups. The experimental group exposed to cell phone devices with a carrier frequency of $915 \mathrm{MHz}$, for $4 \mathrm{~h}$ a day during 60 consecutive days. After mobile phone exposure, the blood samples and also the renal tissues were taken out for histological and biochemical examinations.

Results: The histological results revealed no light microscopic changes in the kidneys between two groups. Necrosis of the renal tubules epithelium was seen in some of the the sections belonging to the both control and experimental groups. Also, in the mice exposed to cell phone fields, the serum levels of creatinine, urea, chloride and total protein were not significantly altered. Although the serum levels of sodium and bicarbonate showed a significant increase, but the activity of alkaline phosphatase revealed no significant changes in comparison with control group. In addition, there are no morphometric, ultra-structural or light microscopic changes in the kidneys between two groups. In the treated animals; the mitochondria were often deformed in the shape and the cytoplasm of the renal tubules was folded in an abnormal manner.

Conclusion: Based on the study, it could conclude that there is no toxic effect on the mice kidneys after exposure to cell phone radiation.

Keywords: Histology, Electromagnetic fields, Ultrastructure, Mice

\section{Introduction}

In the recent years, the use of electromagnetic devices has been increased due to rapid growth of new technologies relevant to electromagnetic fields (EMFs) including radio communication, electricity and mobile communication $(1,2)$. On the other hands, the use of mobile telephones and similar devices employing pulsed EMFs is increased and mobile telecommunications networks could cause adverse changes in the various organs of our body (3). In fact, mobile phones are an integral part of human lives; which keeping people in touch and communicate with the world around them (4).

Public concerns about the potential health effects of mobile telephones raised by scientists. For example, through previous studies, the cellphone use was found to 
affect health status of the various body organs in the animal species as well as human subjects. Also, there is some evidence for a significant association between EMFs exposure and human lymphoblastic leukemia (5) and also central nervous system tumors (6). Similarly, Shuvy et al (2014) stated that EMF exposure may have detrimental impacts on the cardiovascular system in the rats (7). In addition, it has been investigated that 900 or $1800 \mathrm{MHz}$-emitted from mobile phone induced oxidative stress and renal injury in the rats during pregnancy and also growing offspring (8). Recently, Özorak et al (2013) and also Tunik et al (2013) examined the effects of pulsed and sinusoidal electromagnetic fields on the kidney tissues. They have showed that the electromagnetic field at 50 $\mathrm{Hz}$ for 28 days changed the molecular component of the renal tissue (9, 10). Taking together, there is limited data in literature regarding potential renal toxicity after EMFs exposition. Therefore, this study aims to investigate the probable histological and biochemical alterations of the mice kidney after exposure to cell phone radiation.

\section{Materials and methods}

Animals and experimental design: Experimental procedures were performed in accordance with institutional guidelines for animal care and use in the University of Ilam. Also, during the exposure period, animals had ad-lib access to drinking water and food.

To do the experiments, a total of 40 Balb/C mice, 8 to 9 weeks-old (Laboratory Animals Center of Ilam University, Ilam, Iran) were prepared. The animals were housed in the plastic cages of size $32 \times 19$ $\times 17 \mathrm{~cm} 3$ and maintained in a controlled environment at a temperature of $23 \pm 2^{\circ} \mathrm{C}$, a humidity of $45 \pm 5 \%$ and natural $12: 12 \mathrm{~h}$ light-dark cycle. Animals were allowed to be acclimatized to the laboratory condition for at least a week before commencement of the test.
Mice were randomly allocated into two equal groups $(n=20)$, one control and one experiment. The experimental group was exposed to radiofrequency electromagnetic field from four mobile phones (Nokia 1208 model), which operates with microwave carrier frequencies in the range $915 \mathrm{MHZ}(3,11)$. The exposure time was from 8:00 am to 12:00 noon continuously for 60 days. The treatment was done in special plastic cages, the cell phone being placed under the cage at a distance $0.5 \mathrm{~cm}$ below the undersurface of the cage (12), and the cell phones were kept in the talking mode, receiving calls from another phones during hours of EMF exposure, but in silent mode, during the whole time of exposure. Control group of animals was kept under similar environmental conditions, but they exposed to mobile phones system without battery and lack of electromagnetic source.

Biochemical and histomorphological analysis: At the end of the experiment, blood was collected by cardiac puncture and then was centrifuged at $4^{\circ} \mathrm{C}, 5000 \mathrm{rpm}$ for 10 minutes. Then the eluted sera were transferred into newly labeled tubes and stored at $-70{ }^{\circ} \mathrm{C}$ until further analysis. The levels of sodium and potassium in the serum were determined using flame photometry method. In addition, the serum concentration of chloride was determined by using mercuric citrate method (13). The concentrations of blood urea nitrogen (BUN), creatinine (CRT), total protein (TP) and alkaline phosphatase (ALP) were determined by the method of Marsh et al. (14), Slot (15), Lowry et al. (16) and Bessey et al. (17), respectively.

For histological examinations, the kidney specimens were fixed in the formalin $10 \%$; then sectioned by microtome at $6 \mu \mathrm{m}$ and mounted on the glassy slides. The prepared slides were stained with hematoxylin-eosin method and characterized using a light microscope and then analyzed using a digital camera.

For ultrastructural examinations, the specimens were fixed in the $2.5 \%$ 
glutaraldehyde and post fixed with $1 \%$ osmium tetroxide in phosphate-buffered saline for 2 hours. Dehydration stage was carried out by using ascending dilutions of ethanol. Then specimens placed in propylene oxide and embedded in Epon 812. Semi-thin sections were stained with toluidine blue for studying under light microscopy and then $60-80 \mathrm{~nm}$ sectioned samples were stained by uranyl acetate and lead citrate. Finally, structural sections were examined under transmission electron microscopy (Zeiss 902, Germany).

Data analysis and statistics: The statistical analysis of the data was carried out by using SPSS software and all results were presented as mean \pm standard error. In addition, quantitative data were examined by Bartlett's method for homogeneity of variance. In the case of quantitative parameters; an independent two-sample ttest with unequal sample sizes and equal variance was performed to compare the values between experimental and control groups. When the hypothesis of homogeneity of variance was rejected, the Kruskal-Wallis test was used. A probability of $\mathrm{P}<0.05$ was considered significant.

\section{Results}

On the basis of statistical analysis, in the cell phone treated group no significant alterations in the mean of the serum levels of creatinine, urea, chloride and total protein were seen. Also, the serum levels of sodium and bicarbonate showed a significant increase $(\mathrm{P}<0.05)$ but the activity of alkaline phosphatase showed not altered $(\mathrm{P}<0.05)$ in comparison with control group (Table 1).

The effects of cell phone exposure on the renal histology are shown in the figures 1 and 2. Based on the light microscopic studies, cell phone exposure could not alter the histological parameters of the kidney. At higher magnification, the structural properties of the kidneys were not found to be different between two groups (Figure 2). Only necrosis of the renal tubular epithelium was seen in the some of the transverse section of the both control and experimental groups. (Figures 1 to 2 ).

The results of the ultrastructure examinations of the two groups are inserted in figures 3 and 4 . There are no significant alterations in the ultrastructural details of the kidney of the treated mice in comparison with control group. The basement membrane of the renal glomeruli was normal and has not any deposits. In addition, the process of the pedicle of podocytes was normally arranged and has not any adhesion (Figure $3)$. Furthermore, in the treated mice with cell phone radiation; the mitochondrial shapes were deformed and also the cytoplasm of the convoluting tubules was folded in an abnormal manner (Figure 4).

Table 1. Biochemical parameter changes in mice exposed to mobile phone radiation.

\begin{tabular}{lcc}
\hline Biochemical parameters & Control & Cell phone exposed \\
\hline Bicarbonate $(\mathrm{mmol} / \mathrm{L})$ & $18.04 \pm 0.22^{\mathrm{a}^{*}}$ & $26.73 \pm 0.38^{\mathrm{b}}$ \\
Total protein $(\mathrm{g} / \mathrm{dL})$ & $4.17 \pm 0.33$ & $4.14 \pm 0.56$ \\
Chloride $(\mathrm{mmol} / \mathrm{L})$ & $99.65 \pm 1.71$ & $99.05 \pm 1.58$ \\
Sodium $(\mathrm{mmol} / \mathrm{L})$ & $149.90 \pm 2.17^{\mathrm{a}}$ & $180.77 \pm 1.49^{\mathrm{b}}$ \\
Potassium $(\mathrm{mmol} / \mathrm{L})$ & $7.23 \pm 0.34$ & $7.26 \pm 0.76$ \\
BUN $(\mathrm{mg} / \mathrm{dL})$ & $32.36 \pm 1.98$ & $35.02 \pm 1.05$ \\
CRT $(\mathrm{mg} / \mathrm{dL})$ & $0.34 \pm 0.78$ & $0.35 \pm 0.23$ \\
ALP $(\mathrm{U} / \mathrm{L})$ & $58.12 \pm 1.48$ & $59.07 \pm 1.09$ \\
\hline
\end{tabular}

* Significant differences at P < 0.05. CRT: creatinine. ALP: alkaline phosphatase, BUN: blood urea nitrogen. 


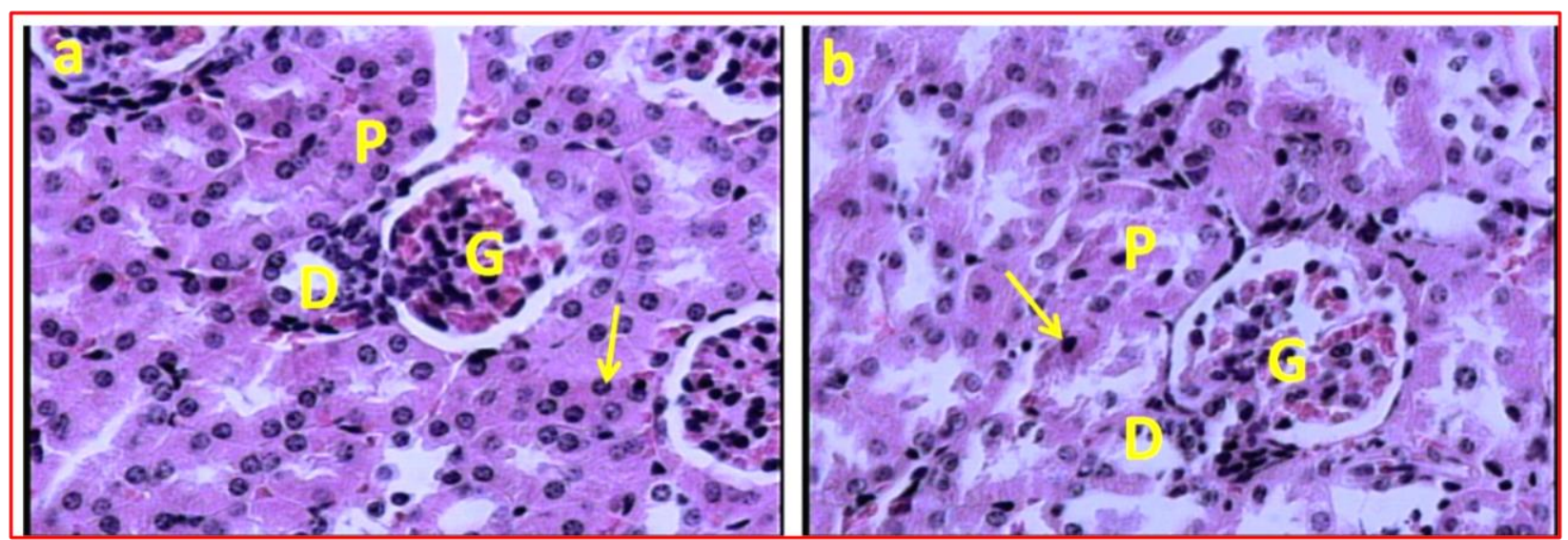

Figure 1. (a): Light microscopic feature of cortical part of the kidney in the control mice; showing normal renal tissue. (b): Light microscopic renal feature in the mice treated with cell phone radiation for 60 days. The section shows no any renal histological changes. The arrows indicate necrosis of the epithelial cells in the renal tubules. (D): distal renal tubules, $(\mathrm{G})$ : glomerule and $(\mathrm{P})$ : proximal renal tubules (Haematoxylin and Eosine method) $(\mathrm{a}, \mathrm{b}: \times$ 400).

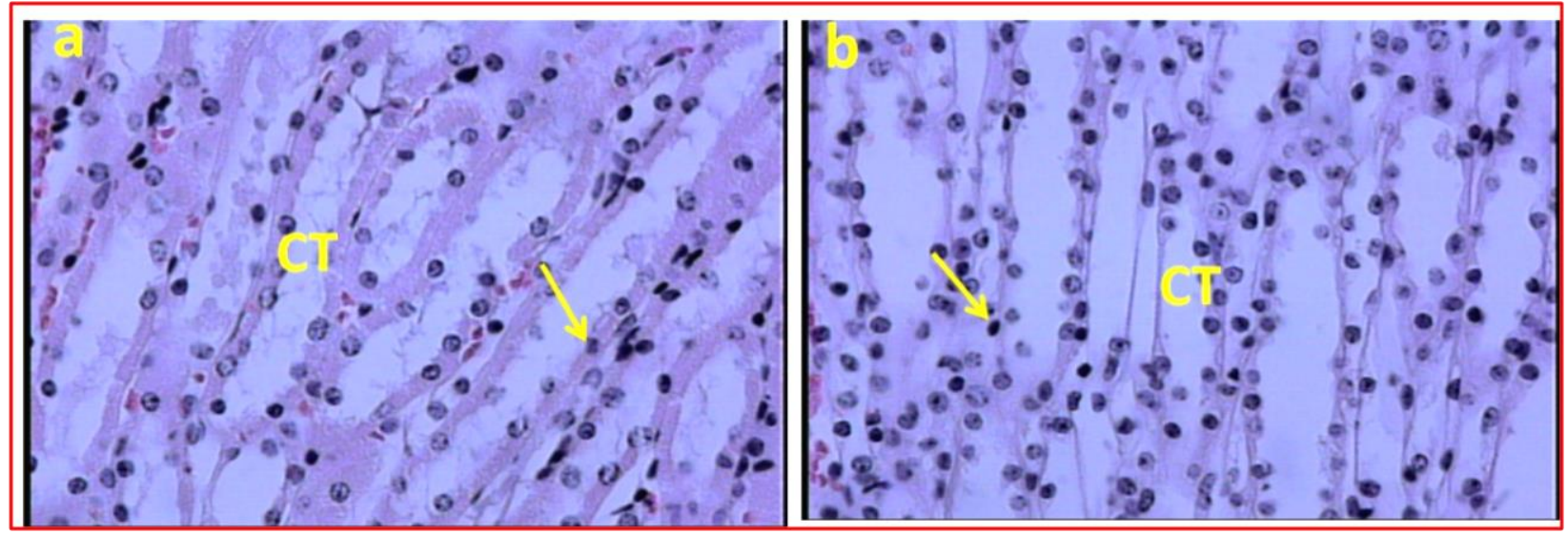

Figure 2. (a): Light microscopic feature of medullar part of the kidney in the control mice showing normal renal tissue. (b): Light microscopic feature of the mice exposed to cell phone radiation for 60 days. The section shows no any renal histological changes. The arrows indicate necrosis of the renal tubules epithelium in the collecting ducts. $(\mathrm{CT})$ : Collecting tubules. (Haematoxylin and Eosine method) $(\mathrm{a}, \mathrm{b}: \times 400)$.

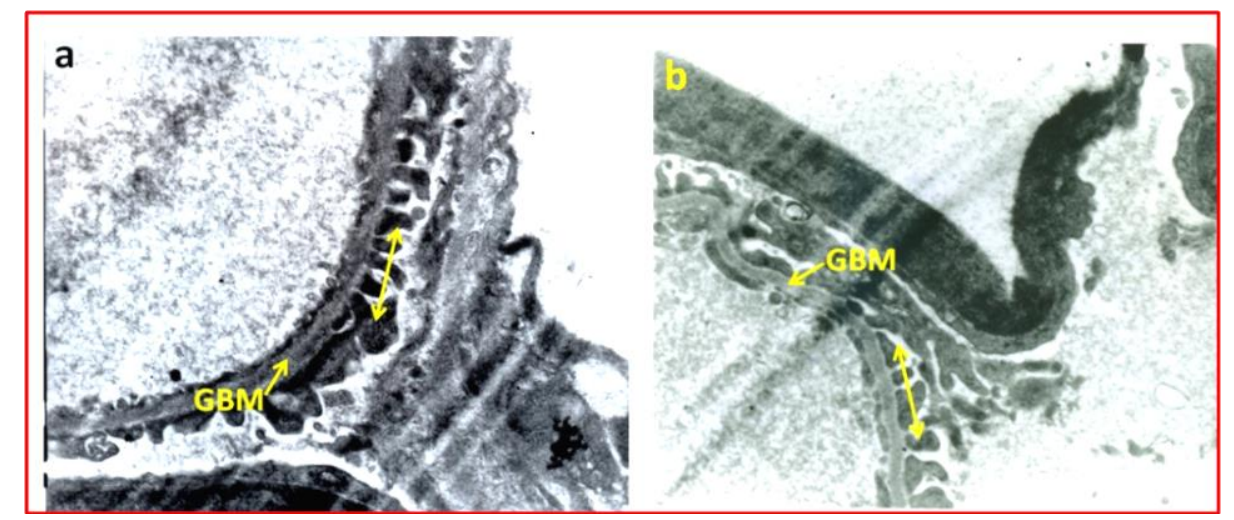

Figure 3. (a): Representative ultra-structural features of kidney in control mice, showing part of glomerus. (b): Photomicrographs of representative ultra-structural features of kidney in the treated mice with mobile phone radiation. In these electron micrographs the basement membrane of the renal glomerule (GBM) is normal and has not any deposits. In addition, the process of the pedicle of podocytes (double head arrows) is normally arranged and has not any adhesion. 


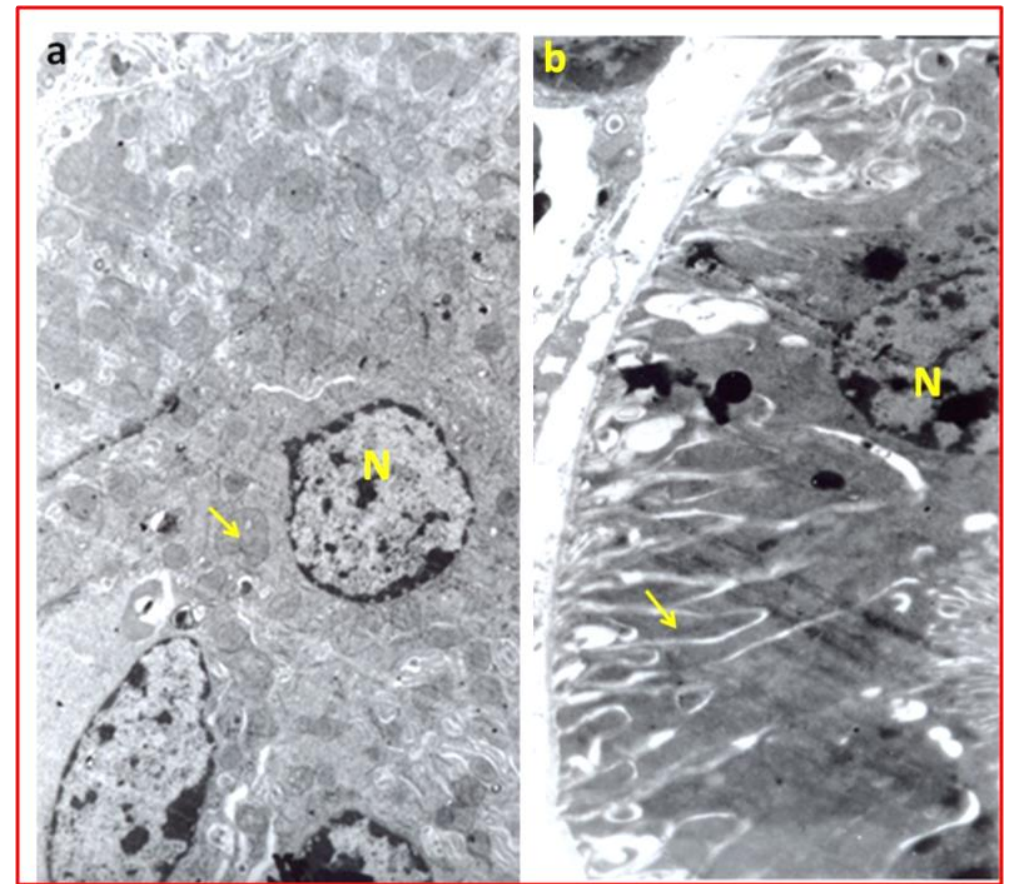

Figure 4. (a): Representative ultra-structural features of kidney in the control mice, showing part of lining cells of proximal convoluting tubules. This figure shows that the nucleus $(\mathrm{N})$ and mitochondria (arrow) have a normal ultra-structure. (b): Photomicrographs of representative ultra-structural features of kidney in the treated mice with cell phone radiation; showing part of lining cells of proximal convoluting tubules. The mitochondrial shapes are deformed and also the cytoplasm of the convoluting tubules is folded in an abnormal manner.

\section{Discussion}

Public health concerns about the potential hazardous effects from recently developed devices include mobile telephones raised by scientists. Mobile telephones are the leading devices that emit EMFs and have an increasing use worldwide (4). In the current study, the biochemical and structural changes of the kidney in the mice exposed to electromagnetic field emitted by cell phones radiation was evaluated.

In the present study, the histopathological or biochemical examinations showed no significant renal alterations after exposure to the electromagnetic fields with a carrier frequency of $915 \mathrm{MHz}$ for 60 days. Overall, both light and electron microscopic examinations of the kidneys from experiment group clearly demonstrated normal tissue and no significant changes in the structural integrity when compared with controls. Present finding disagrees with the finding of Oktem et al (8). It is possible that the different results might be due to the diverse equipment protocols and various experimental methods and also in the intensity of the applied EMFs (18).

In the present study, the lack of any EMFs related histopathological alterations in the renal tissue suggest that applied cell phone radiation evoked only some fine biochemical changes, which are not important histologically.

Estimation of kidney excretion of waste metabolites and histological alterations in the renal tissue has evoked useful information on the health status of the kidneys (19). In the current study, not significant alterations were seen in terms of creatinine and also BUN in the cell phone treated mice. Creatinine and BUN are chemical waste products due to protein metabolism which transported through the bloodstream to the kidneys to be excreted in the urine (19).

In the present investigation, the activity of alkaline phosphatase enzyme showed no 
significant alterations in comparison with control group. Since estimation of alkaline phosphatase levels provides the most useful information on the biochemical status of the kidney; therefore, these findings imply that applied cell phone radiation not affected the functional aspect of the kidneys.

In the current study, mitochondria were often deformed in the shape and the cytoplasm of the convoluting tubules was folded in an abnormal manner. These findings are in line with the results from previous investigation (20).

\section{References}

1. Hitchcock RT, Patterson RM. Radiofrequency and ELF electromagnetic energies: a handbook for health professionals. New York, USA: Van Nostrand Reinhold; 1995.

2. Mikolajczyk H. Biological effects of electromagnetic fields below $300 \mathrm{MHz}$ (pregnancy, litter size and gonadotropic activity of the anterior pituitary gland). Med Pract. 1978; 29(2): 111-20.

3. Forgács Z, Somosy Z, Kubinyi G, Bakos J, Hudák A, Surján A, et al. Effect of whole-body $1800 \mathrm{MHz}$ GSM-like microwave exposure on testicular steroidogenesis and histology in mice. Reprod Toxicol. 2006; 22(1):111-7 .

4. Narayanan SN, Kumar RS, Potu BK, Nayak S, Bhat PG, Mailankot $M$. Effect of radio-frequency electromagnetic radiations (RF-EMR) on passive avoidance behavior and hippocampal morphology in Wistar rats. Upsala J Med Sci. 2010; 115(2):91-6.

5. Kundi M. EMFs and childhood leukemia. Environ Health Perspect. 2007; 115(8):A395.

6. Baan R, Grosse Y, Lauby-Secretan B. Carcinogenicity of radiofrequency electromagnetic fields. Lancet Oncol. 2011; 12(7): 624-6.
Further experimental studies in animal models and carefully designed casecontrolled investigations in humans are required to elucidate the consequences of cell phone exposure renal complications .

The limitation of the present study was the lack of molecular research accompanying histological changes.

Taking together, upon to this study we conclude that EMFs exposition with a carrier frequency of $915 \mathrm{MHz}$; during 60 days could not causes toxic alterations in the mice kidney.

7. Shuvy M, Abedat S, Beeri R, Valitzki $\mathrm{M}$, Stein Y, Meir K, et al. Electromagnetic fields promote severe and unique vascular calcification in an animal model of ectopic calcification. Exp Toxicol Pathol. 2014; 66(7):34550.

8. Oktem F, Ozguner F, Mollaoglu H, Koyu A, Uz E. Oxidative damage in the kidney induced by $900-\mathrm{MHz}-$ emitted mobile phone: protection by melatonin. Arch Med Res. 2005; 36(4):350-5.

9. Özorak A, Nazıroğlu M, Çelik Ö, Yüksel M, Özçelik D, Özkaya MO, et al. Wi-Fi $(2.45 \mathrm{GHz})$ and mobile phone (900 and $1800 \mathrm{MHz}$ )-induced risks on oxidative stress and elements in kidney and testis of rats during pregnancy and the development of offspring. Biol Trace Elem Res. 2013; 156(1-3):221-9.

10. Tunik S, Ayaz E, Akpolat V, Nergiz Y, Isen K, Celik MS, et al. Effects of pulsed and sinusoidal electromagnetic fields on MMP-2, MMP-9, collagen type IV and E-cadherin expression levels in the rat kidney: an immunohistochemical study. Anal Quant Cytopathol Histpathol. 2013; 35(5):253-60.

11. Peter AVT, Emilie VD, Michael HR. Workgroup Report: Base Stations and Wireless Networks-Radiofrequency (RF) Exposures and Health 
Consequences. Environ Health Perspect. 2007; 115(3):416-24.

12. Aksen F, Dasdag S, Akdag MZ, Askin Dasdag MM. The Effects of Whole Body Cell Phone Exposure on the T1 Relaxation Times and Trace Elements in the Serum of Rats. Electromagnet Biol Med. 2004; 23(1):7-17.

13. Schaless C, Schaless SS. Estimation of serum chloride using mercuric citrate method. J Boil Chem. 1941; 140(1): 879-86.

14. Marsh WH, Fingerhut B, Miller H. Automated and manual direct methods for the determination of blood urea. $\mathbf{J}$ Clin Chem. 1965; 11(5): 624-7.

15. Slot C. Plasma creatinine determination. A new and specific Jaffe reaction method. Scand J Clin Lab Invest. 1965; 17(4): 381-7.

16. Lowry OH, Rosebrough NJ, Farr AL, Randall RJ. Protein measurement with the folin phenol reagent. J Biol Chem. 1951; 193(1): 265-75.

17. Bessey OA, Lowry OH, Brock MJ. A method for the rapid determination of alkaline phosphatase with 5 cubic millimeters of serum. J Biol Chem. 1946; 164: 321-9.

18. Brent RL. Reproductive and teratologic effects of low-frequency electromagnetic fields: a review of in vivo and in vitro studies using animal models. Teratology. 1999; 59(4):26186.

19. Panda, NC. Kidney in: Textoobk of Biochemistry and Human biology. 2nd ed. Prentise hall India: pp: 296-290. Publishers, Owerri Nigeria, pp: 65134. 1999.

20. Koca O, Gökçe AM, Öztürk MI, Ercan F, Yurdakul N, Karaman MI. Effects of intensive cell phone (Philips Genic $900)$ use on the rat kidney tissue. Urol J. 2013; 10(2):886-91. 